\title{
Distinct Effects of Bovicin HC5 and Virginiamycin on in vitro Ruminal Fermentation and Microbial Community Composition
}

\author{
Sofia Magalhaes Moreira ${ }^{1}$, Claudia Braga Pereira Bento ${ }^{1}$, Analice Claudia Azevedo ${ }^{1} \&$ Hilario C. Mantovani ${ }^{1}$ \\ ${ }^{1}$ Departamento de Microbiologia, Universidade Federal de Vicosa, Vicosa, Minas Gerais, Brazil \\ Correspondence: Hilario Mantovani, Departamento de Microbiologia, Universidade Federal de Vicosa, \\ 36570-900, Vicosa, Minas Gerais, Brazil. E-mail: hcm6@ufv.br
}

Received: April 29, 2018

Accepted: June 3, $2018 \quad$ Online Published: July 15, 2018

doi:10.5539/jas.v10n8p156

URL: https://doi.org/10.5539/jas.v10n8p156

\begin{abstract}
Antibiotics are used as feed additives for cattle to alter rumen fermentation and increase weight gain. However, this practice can potentially lead to the presence of antibiotic residues in milk and meat and the selection of multiresistant bacteria. Bacteriocins have been suggested as an alternative to antibiotics used in animal production. This work aimed to evaluate the in vitro effects of bovicin HC5 and virginiamycin on ruminal fermentation and on microbial community composition. Ruminal fluid was collected from fistulated cows fed corn silage and incubated with Trypticase $\left(15 \mathrm{~g} \mathrm{~L}^{-1}\right)$. Cultures treated with bovicin HC5 or virginiamycin decreased $(P<0.05)$ ammonia accumulation by $47.46 \%$ and $66.17 \%$, respectively. Bovicin HC5 and virginiamycin also decreased $(P<0.05)$ the concentration of organic acids and gas production, but the effects were somewhat distinct. Molecular fingerprinting of the microbial community using PCR-DGGE revealed that community structure varied between treatments and were distinct from the controls. These results demonstrate that bovicin HC5 and virginiamycin have distinct effects on ruminal fermentation and modify differently the microbial community composition. These results also expand the knowledge about the effects of antibiotics and bacteriocins on bacterial and archaeal communities involved in protein metabolism in the rumen.
\end{abstract}

Keywords: antibiotics, bacteriocins, deamination, feed additives, PCR-DGGE

\section{Introduction}

In ruminant livestock, feedstuffs are fermented by rumen microorganisms generating microbial protein, volatile fatty acids (VFAs), ammonia, methane and heat (Rychlik \& Russell, 2000; Bach et al., 2005). Much of these products are used as protein and energy sources by the host, but dietary losses due to urea excretion and methane production can raise the cost of production of dairy and beef cattle.

For decades, ruminant nutritionists have used chemical additives in rations of dairy and beef cattle to decrease dietary losses and increase useful end-products of ruminal fermentation, thus enhancing the efficiency of feed utilization (Callaway et al., 1997; Shen et al., 2017). Ionophore antibiotics are the most commonly used feed additives for manipulation of rumen fermentation in cattle (Patra, 2012). However, the European Union and countries in Asia have gradually banned the use of antibiotics as growth promoters in food-producing animals between 1997 and 2006 (Maron et al., 2013). Therefore, several alternatives to growth promoters have been sought by farmers and ruminant nutritionists to reduce feeding costs, to maintain animal health and growth performance, and to decrease the environmental impact of animal production systems. Among these, several feeding management strategies and chemical and biological additives are being investigated as potential alternatives to control or manipulate the processing and assimilation of dietary nutrients.

Chemical and biological additives such as essential oils, non-ionophore antibiotics, antimicrobial peptides, yeasts, probiotics and direct-fed microbials could be dosed in-feed to entire herds of ruminants, a route typically used for prophylaxis, metaphylaxis, and growth promotion of production animals (Cameron \& McAllister, 2016). Previous work demonstrated that antimicrobial peptides could have a role modulating the utilization of dietary nutrients and bovicin HC5, a ruminal bacteriocin, inhibited amino acid deamination and methane production by rumen microorganisms in vitro (Lee et al., 2002). However, its effect on microbiota composition and other fermentation parameters has not been investigated. In this work, we aimed to evaluate the in vitro activities of bovicin HC5 and virginiamycin, a non-ionophore antibiotic that has been successfully applied to improve feed efficiency in different livestock production systems, and evaluate if a ruminal bacteriocin would have similar 
effects on ruminal fermentation as commercially used feed additives. We focused our analysis on amino acid utilization by the rumen microbiota due to the fact that protein is the most expensive component of ruminant rations and both inhibitors appear to have protein-sparing effects.

\section{Methods}

\subsection{Microorganisms and Culture Conditions}

Streptococcus equinus HC5 was routinely cultivated under anaerobic conditions $\left(39^{\circ} \mathrm{C}, 18 \mathrm{~h}\right)$ in basal medium as previously described by Mantovani and Russell (2001). Alicyclobacillus acidoterrestris DSMZ 2498 was cultivated $\left(43^{\circ} \mathrm{C}, 16 \mathrm{~h}\right.$ ) under aerobic conditions in BAM (Bacillus acidocaldarius medium) medium containing

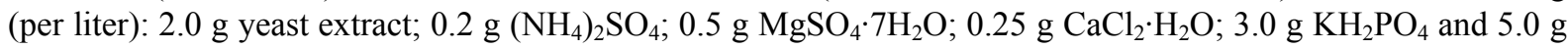
glucose. The $\mathrm{pH}$ was adjusted to 4.0 with $1 \mathrm{M} \mathrm{HCl}$.

\subsection{Preparation of Antimicrobial Agents}

Previously, we demonstrated by reverse-phase HPLC analysis that $S$. equinus HC5 semi-purified extracts had only one peak with antimicrobial activity corresponding to bovicin HC5 (Lima et al., 2009). Briefly, stationary phase $S$. equinus $\mathrm{HC} 5$ cultures ( $1 \mathrm{~L}, c$. $400 \mu \mathrm{g} \mathrm{mL}^{-1}$ microbial protein) were harvested by centrifugation $(1710 \mathrm{~g}$, $\left.10 \mathrm{~min}, 4^{\circ} \mathrm{C}\right)$. The cell pellets were washed and resuspended in acidic sodium chloride $\left(100 \mathrm{mmol} \mathrm{L}^{-1}, \mathrm{pH} 2.0\right.$, $\left.39^{\circ} \mathrm{C}, 2 \mathrm{~h}\right)$. The cell suspensions were then centrifuged $\left(1710 \mathrm{~g}, 10 \mathrm{~min}, 4{ }^{\circ} \mathrm{C}\right)$, and the cell-free supernatants were stored at $-20{ }^{\circ} \mathrm{C}$ until use. The antimicrobial activities of the bovicin HC5 extracts were evaluated by agar well-diffusion assays (Tagg et al., 1976). Semi-purified extracts of bovicin HC5 were serially diluted (2-fold increments) in phosphate solution $\left(5 \mathrm{mmol} \mathrm{L}^{-1}, \mathrm{pH} 2.0\right)$ and assayed for antimicrobial activity using Alicyclobacillus acidoterrestris DSMZ 2498 as the indicator organism $\left(10^{6} \mathrm{CFU} \mathrm{mL}^{-1}\right)$. Bacteriocin activity was expressed as arbitrary unit (AU), defined as the reciprocal of the highest dilution that showed a zone of inhibition with at least $5 \mathrm{~mm}$ in diameter (Lewus et al., 1991). Stock solutions of bovicin HC5 had an activity of 40,960 $\mathrm{AU} \mathrm{mL}^{-1}$.

Virginiamycin (Phigrow ${ }^{\circledR}$ ) was obtained from Phibro Corporation Ltd. The commercial preparation was composed by $10 \%$ virginiamycin and $90 \%$ calcium carbonate. The virginiamycin solution $\left(1.0 \mathrm{mmol} \mathrm{L}^{-1}\right)$ was prepared dissolving the commercial additive in sterilized distilled water prepared under anaerobic conditions with $\mathrm{O}_{2}$-free nitrogen $\left(\mathrm{N}_{2}\right)$. The virginiamycin solution was prepared fresh in the same day the incubations were carried out.

\subsection{Animal Sampling and in vitro Incubations}

Ruminal fluid was collected from rumen-cannulated dairy cows about two hours after feeding. All procedures were performed in accordance with a protocol approved by the Universidade Federal de Viçosa Ethics and Animal Care and Use Committee ( $\mathrm{n}^{\circ}$ 05/2016). The diet of animals sampled consisted of corn silage (31.2\% DM; $7.2 \% \mathrm{CP} ; 54.5 \% \mathrm{NDF}$ and $2.8 \% \mathrm{EE})$ and $30 \%$ concentrate $(89.4 \% \mathrm{DM} ; 28.1 \% \mathrm{CP} ; 13.3 \% \mathrm{NDF}$ and $2.7 \% \mathrm{EE})$ (Valadares Filho et al., 2016), provided ad libitum. Ruminal digesta was filtered through four layers of cheesecloth into thermal containers and transported to the laboratory. Rumen fluid was anaerobically transferred to tubes and centrifuged $(500 \mathrm{~g}, 5 \mathrm{~min})$ to remove feed particles. The supernatant $(35 \mathrm{~mL})$ was anaerobically transferred to serum bottles and Trypticase was added as a source of peptides and amino acids to a final concentration of $15 \mathrm{~g} \mathrm{~L}^{-1}$. The study was conducted in a completely randomized design performed in triplicate with two inhibitors and four doses of each inhibitor. Concentrations of bovicin HC5 were $0 ; 500 ; 1,000$ and $2,000 \mathrm{AU} \mathrm{mL}^{-1}$, while the following concentrations of virginiamycin were used $0 ; 5 ; 10$ and $20 \mu \mathrm{mol} \mathrm{\textrm {L } ^ { - 1 }}$. The in vitro incubations were carried out in $50 \mathrm{~mL}$ anaerobic serum bottles containing $35 \mathrm{~mL}$ of rumen contents (final volume) incubated under stirring ( $160 \mathrm{rpm})$ at $39^{\circ} \mathrm{C}$ for $24 \mathrm{~h}$.

\subsection{Analysis of Ammonia Concentration, Microbial Protein and Amino Acid Deamination Activity}

Concentration of ammonia in ruminal fluid $(1 \mathrm{~mL})$ was monitored according to the method of Chaney and Marbach (1962). Absorbance at $630 \mathrm{~nm}$ was measured in a spectrophotometer Spectronic 20D (Thermo Fisher Scientific, Madison, WI, USA) and ammonium chloride $\left(\mathrm{NH}_{4} \mathrm{Cl}\right)$ was used as the standard. Total ammonia $\left(\mathrm{mmol} \mathrm{L}^{-1}\right)$ was expressed as the difference in ammonia concentration determined after $24 \mathrm{~h}$ of incubation and the initial concentration of ammonia $(0 \mathrm{~h})$. Concentration of microbial protein was determined according to the colorimetric method of Bradford (1976), using lysozyme as the standard. Specific activity of deamination was calculated from the difference in ammonia concentration $\left(\mathrm{mmol} \mathrm{L}^{-1}\right)$ between the times zero and six hours of incubation, divided by microbial protein concentration $\left(\mathrm{mg} \mathrm{L}^{-1}\right)$ and the incubation time (minutes). 


\subsection{Analysis of the Bacterial and Archaeal Community by Denaturing Gradient Gel Electrophoresis (PCR-DGGE)}

Changes in diversity of the ruminal bacterial and archaeal community caused by the addition of antimicrobials (bovicin or virginiamycin) was assessed in rumen fluid samples $(25 \mathrm{~mL})$ collected after 24 hours of incubation. The samples were stored at $-80{ }^{\circ} \mathrm{C}$ and defrosted at room temperature immediately before being processed for DNA extraction, using the phenol-chloroform procedure described by Stevenson and Weimer (2007). Genomic DNA extracted from the rumen fluid was utilized in the amplification reactions using primers specific for the V3 region of the 16S rRNA of the Bacteria and Archaea (Muhling et al., 2008; DeLong, 1992). The regions V3-V4 and of V4-V5 the 16S rRNA of the Fimicutes and Bacteroidetes phyla, respectively, were also amplified to investigate changes in community composition within these phylogenetics groups (Muhling et al., 2008).

PCR reactions were performed in a Biocycler MG96G (São Paulo, Brazil) using the primers and amplification conditions previously described (Bento et al., 2016). DGGE was performed in a DGGE-2401 apparatus (CBS Scientific Company, San Diego, CA, USA) as previously described (Bento et al., 2016). The software Bionumerics 7.5 (Applied Maths, Kortrijk, Belgium) was used to analyze the bands in the DGGE gel. Comparison of the data sets was based on Dice's similarity coefficient with the optimization and tolerance parameters set at $1.0 \%$. Clustering was performed using the unweighted pair group method (UPGMA). Shannon-Wiener index was calculated using the Past software (Hammer et al., 2001).

\subsection{Analysis of Organics Acids, $\mathrm{pH}$ and Gas Production}

Organic acids were analyzed by high performance liquid chromatography (HPLC) using a Dionex Ultimate 3000 Dual detector HPLC (Dionex Corporation, Sunnyvale, CA, USA) coupled to a refractive index (RI) Shodex RI-101 detector maintained at $40{ }^{\circ} \mathrm{C}$. Separation was performed in a Phenomenex Rezex ROA column $(300 \times$ $7.8 \mathrm{~mm})$ maintained at $45{ }^{\circ} \mathrm{C}$. The mobile phase was $5 \mathrm{mmol} \mathrm{L}^{-1}$ sulfuric acid $\left(\mathrm{H}_{2} \mathrm{SO}_{4}\right)$ and the flow rate was maintained at $0.7 \mathrm{~mL} \mathrm{~min}$. Rumen fluid samples $(2.0 \mathrm{~mL})$ were harvested after 24 hours of incubation, centrifuged $(12,000 \times \mathrm{g}, 10 \mathrm{~min})$ and the cell-free supernatants were treated as described by Siegfried et al. (1984).

The $\mathrm{pH}$ values of the in vitro cultures were recorded at 0,6 and $24 \mathrm{~h}$ of incubation using a pH meter (Model TEC-2 mp, Tecnal Scientific Equipments, Piracicaba, Brazil). The volume $(\mathrm{mL})$ of total gas accumulation was measured using lubricated syringes that were coupled to the fermentation bottles at time 6 and 24 hours of incubation (Theodorou et al., 1994).

\subsection{Statistical Analysis}

All in vitro incubations were performed in triplicate and with three biological replicates. The data were subjected to analysis of variance (ANOVA) and significant differences were analyzed with the Tukey's test using the Statistical Analysis System and Genetics software (Ferreira, 2011). Differences among means with $P<0.05$ were considered statistically significant.

\section{Results}

When ruminal microbiota were incubated in vitro with Trypticase $\left(15 \mathrm{~g} \mathrm{~L}^{-1}\right)$, the specific activity of deamination and ammonia accumulation were $36.11 \mathrm{nmol}$ of $\mathrm{NH}_{3} \mathrm{mg}$ protein $^{-1} \min ^{-1}$ and $57.49 \mathrm{mmol} \mathrm{L}^{-1}$, respectively (Table 1). Addition of bovicin $\mathrm{HC} 5$ or virginiamycin to the incubated cultures did not affect the concentration of microbial protein, but most of the other parameters being evaluated were influenced by one or both of the inhibitors. The ruminal $\mathrm{pH}$ decreased $(P<0.05)$ with the addition of $2,000 \mathrm{AU} \mathrm{mL}^{-1}$ bovicin $\mathrm{HC} 5$ or with 10 and $20 \mu \mathrm{mol} \mathrm{L}{ }^{-1}$ virginiamycin compared to the controls.

Bovicin HC5 did not affect $(P>0.05)$ synthesis of microbial protein and the specific activity of deamination (SAD). However, a significant decrease in total ammonia accumulation $\left(47.46 \%\right.$ reduction in $\left.\mathrm{NH}_{4}{ }^{+}\right)$was observed with the addition of 2,000 $\mathrm{AU} \mathrm{mL}^{-1}$ (Figure 1A). In the case of virginiamycin a reduction in SAD was observed at $10 \mu \mathrm{mol} \mathrm{L}{ }^{-1}$, while ammonia concentration was inhibited by $66.17 \%$ with the addition $20 \mu \mathrm{mol} \mathrm{L}$ of $^{-1}$ the inhibitor (Figure 1B). Differences $(P<0.05)$ were also observed for the interactions control vs antimicrobials (57.49 vs 28.59 ) in the SAD and for bovicin HC5 vs virginiamycin (33.63 vs 24.82) in the quantification of ammonia accumulation (Table 1).

Bovicin HC5 and virginiamycin decreased $(P<0.05)$ the concentration of total organic acids produced during ruminal fermentation in vitro (Table 1). The addition of bovicin HC5 or virginiamycin decreased $(P<0.05)$ the concentration of isobutyric acid, valeric acid, and isovaleric acid. Bovicin HC5 increased the concentration of acetic and propionic acid and the acetate:propionate ratio was not affected. Treatments containing virginiamycin increased $(P>0.05)$ the concentration of propionic acid and showed lower $(P<0.05)$ acetate:propionate ratios 
compared to controls. Total gas production also decreased $(P<0.05)$ throughout the fermentation when bovicin HC5 or virginiamycin were added to the cultures, being reduced by $32 \%$ and $53 \%$, respectively, when compared to the controls (Table 1).

Diversity analysis of Bacteria and Archaea domains and different bacterial phyla by denaturing gradient gel electrophoresis (DGGE) revealed higher similarity of the microbial communities within each treatment and lower similarity between treatments (Figure 2). Analysis of the band profiling in ruminal fluid generated from this study revealed 38, 41, 56, and 29 bands for the domain Bacteria, phylum Firmicutes, phylum Bacteroidetes and domain Archaea, respectively (data not shown). The structure of the microbial community (domain Bacteria and phylum Bacteroidetes) in samples treated with bovicin HC5 were more similar to the controls compared to the samples treated with virginiamicin (Figures $2 \mathrm{~A}$ and $2 \mathrm{~B}$ ).

Table 1. Effect of bovicin HC5 and virginiamycin on ruminal fermentation parameters in vitro

\begin{tabular}{|c|c|c|c|c|c|c|c|c|c|c|c|}
\hline \multirow{2}{*}{ Parameters } & \multirow{2}{*}{ Control } & \multicolumn{3}{|c|}{ Bovicin $\mathrm{HC} 5\left(\mathrm{AU} \mathrm{mL}^{-1}\right)$} & \multicolumn{3}{|c|}{ Virginiamycin $\left(\mu \mathrm{mol} \mathrm{L}^{-1}\right)$} & \multicolumn{2}{|c|}{$P$-Value } & \multicolumn{2}{|c|}{ Contrast $^{*}$} \\
\hline & & 500 & 1,000 & 2,000 & 5 & 10 & 20 & Bov & Virg & Cont. vs Ant. & Bov. vs Virg. \\
\hline $\mathrm{pH}$ & $6.52^{\mathrm{a}}$ & $6.53^{\mathrm{a}}$ & $6.49^{\mathrm{ab}}$ & $6.44^{b}$ & $6.51^{\mathrm{a}}$ & $6.28^{\mathrm{b}}$ & $6.30^{\mathrm{b}}$ & 0.01 & $<0.01$ & 0.04 & $<0.01$ \\
\hline Protein $^{1}$ & 909.29 & 862.96 & 937.37 & 876.70 & 881.52 & 897.14 & 873.17 & 0.76 & 0.94 & 0.61 & 0.83 \\
\hline $\mathrm{SAD}^{2}$ & $36.11^{\mathrm{a}}$ & 33.57 & 28.93 & 29.81 & $35.75^{\mathrm{a}}$ & $25.80^{\mathrm{b}}$ & $29.73^{\mathrm{ab}}$ & 0.08 & $<0.01$ & 0.01 & 0.87 \\
\hline $\mathrm{NH}_{4}^{+3}$ & $57.49^{\mathrm{a}}$ & $37.58^{\mathrm{b}}$ & $32.47^{\mathrm{b}}$ & $30.81^{\mathrm{b}}$ & $34.23^{\mathrm{b}}$ & $21.21^{\mathrm{c}}$ & $19.84^{\mathrm{c}}$ & $<0.01$ & $<0.01$ & $<0.01$ & $<0.01$ \\
\hline $\mathrm{Gas}^{4}$ & $29.90^{\mathrm{a}}$ & $22.33^{\mathrm{b}}$ & $19.80^{\mathrm{b}}$ & $18.50^{\mathrm{b}}$ & $18.08^{\mathrm{b}}$ & $13.41^{\mathrm{b}}$ & $15.16^{\mathrm{b}}$ & 0.02 & $<0.01$ & $<0.01$ & 0.05 \\
\hline Total VFA ${ }^{5}$ & $191.51^{\mathrm{a}}$ & $171.77^{\mathrm{ab}}$ & $168.87^{\mathrm{ab}}$ & $159.52^{\mathrm{b}}$ & $168.79^{\mathrm{b}}$ & $160.23^{b}$ & $158.50^{\mathrm{b}}$ & 0.03 & $<0.01$ & $<0.01$ & 0.48 \\
\hline Acetate $(\mathrm{A})^{6}$ & $56.88^{\mathrm{b}}$ & $60.05^{\mathrm{ab}}$ & $61.10^{\mathrm{ab}}$ & $61.95^{\mathrm{a}}$ & 59.56 & 59.79 & 60.38 & 0.02 & 0.13 & 0.02 & 0.02 \\
\hline Propionate $(\mathrm{P})^{6}$ & $17.05^{\mathrm{c}}$ & $18.30^{\mathrm{b}}$ & $18.85^{\mathrm{a}}$ & $18.98^{\mathrm{a}}$ & $21.26^{\mathrm{b}}$ & $23.67^{\mathrm{a}}$ & $23.26^{\mathrm{a}}$ & $<0.01$ & $<0.01$ & $<0.01$ & $<0.01$ \\
\hline Butyrate $^{6}$ & 10.25 & 11.13 & 11.44 & 11.45 & 10.69 & 9.47 & 9.56 & 0.50 & 0.53 & 0.65 & 0.01 \\
\hline Isobutyrate $^{6}$ & $3.36^{\mathrm{a}}$ & $1.76^{\mathrm{b}}$ & $1.40^{\mathrm{b}}$ & $1.25^{\mathrm{b}}$ & $1.40^{\mathrm{b}}$ & $1.13^{\mathrm{b}}$ & $1.14^{\mathrm{b}}$ & $<0.01$ & $<0.01$ & $<0.01$ & 0.02 \\
\hline Succinate $^{6}$ & $0.00^{\mathrm{c}}$ & $0.30 \mathrm{~b}^{\mathrm{c}}$ & $0.59^{\mathrm{ab}}$ & $0.68^{\mathrm{a}}$ & $0.24^{\mathrm{b}}$ & $0.81^{\mathrm{a}}$ & $0.84^{\mathrm{a}}$ & $<0.01$ & $<0.01$ & $<0.01$ & 0.37 \\
\hline Valerate $^{6}$ & $3.88^{\mathrm{a}}$ & $2.03^{\mathrm{b}}$ & $1.84^{\mathrm{b}}$ & $1.72^{\mathrm{b}}$ & $2.12^{\mathrm{b}}$ & $1.77^{\mathrm{b}}$ & $1.62^{\mathrm{b}}$ & $<0.01$ & $<0.01$ & $<0.01$ & 0.85 \\
\hline Isovalerate $^{6}$ & $8.55^{\mathrm{a}}$ & $6.41^{\mathrm{ab}}$ & $4.74^{\mathrm{b}}$ & $3.94^{\mathrm{b}}$ & $4.71^{b}$ & $3.34^{\mathrm{b}}$ & $3.18^{\mathrm{b}}$ & $<0.01$ & $<0.01$ & $<0.01$ & 0.02 \\
\hline $\mathrm{A}: \mathrm{P}^{7}$ & 3.34 & 3.28 & 3.24 & 3.27 & $2.80^{\mathrm{b}}$ & $2.53^{\mathrm{b}}$ & $2.60^{\mathrm{b}}$ & 0.92 & $<0.01$ & 0.07 & $<0.01$ \\
\hline
\end{tabular}

Note. ${ }^{1}$ Microbial protein $\left(\mathrm{mg} \mathrm{ml}^{-1}\right){ }^{2}$ Specific activity of deamination (SAD; nmol of NH $\left.\mathrm{mg} \mathrm{protein}^{-1} \mathrm{~min}^{-1}\right) .{ }^{3}$ Ammonia concentration $\left(\mathrm{NH}_{4}^{+} ; \mathrm{mmol} \mathrm{l}^{-1}\right) .{ }^{4}$ Total gas concentration $(\mathrm{ml}) .{ }^{5}$ Total volatile fatty acids (Total VFA; mmol $\left.1^{-1}\right) .{ }^{6}$ Acetic acid, propionic acid, butyric acid, isobutyric acid, formic acid, succinic acid, valeric acid and isovaleric acid (\%). ${ }^{7}$ Acetate:Propionate ratio (A:P). ${ }^{8}$ Antimicrobial effects were tested using contrasts. Cont. (control with no antimicrobial); Bov. (different doses of bovicin HC5); Vir (different doses of virginiamycin). Means followed by at least one letter in the line for the different doses of each antimicrobial and control do not differ at $5 \%$ significance level by Tukey test.

Richness analysis and the Shannon-Wiener index were calculated from a binary matrix generated based on the electrophoretic profiles in the DGGE gels using the software BioNumerics 7.5 (Figures 3A and 3B). Our results showed no differences $(P>0.05)$ in species richness and diversity of Firmicutes and Bacteroidetes between the controls and treatments added with bovicin HC5 or virginiamycin. The addition of antimicrobials increased $(P<$ $0.05)$ the species richness and the Shannon-Wiener index of the domain Bacteria; however, only virginiamycin increased $(P<0.05)$ the species richness and the Shannon-Wiener index of the domain Archaea (Figures 3A and B).

\section{Discussion}

The emergence of multidrug resistant bacteria associated with livestock has increased the threat of antibiotic resistance genes being spread throughout the food chain. Therefore, alternatives have been investigated to decrease the use of antibiotics in animal production. Among these, antimicrobial peptides (bacteriocins) produced by Gram-positive bacteria have been evaluated in vitro and in vivo as potential alternatives. Bacteriocins have been traditionally studied as potentially useful biological tools in the food industry (Deegan et al., 2006), but studies demonstrated that these antimicrobials are also effective in controlling animal pathogens (Twomey et al., 2000; Wu et al., 2007). These peptides also show synergistic interactions with antibiotics (Todorov, 2010), and could be useful to manipulate rumen fermentation (Lima et al., 2009; Shen et al., 2017). 

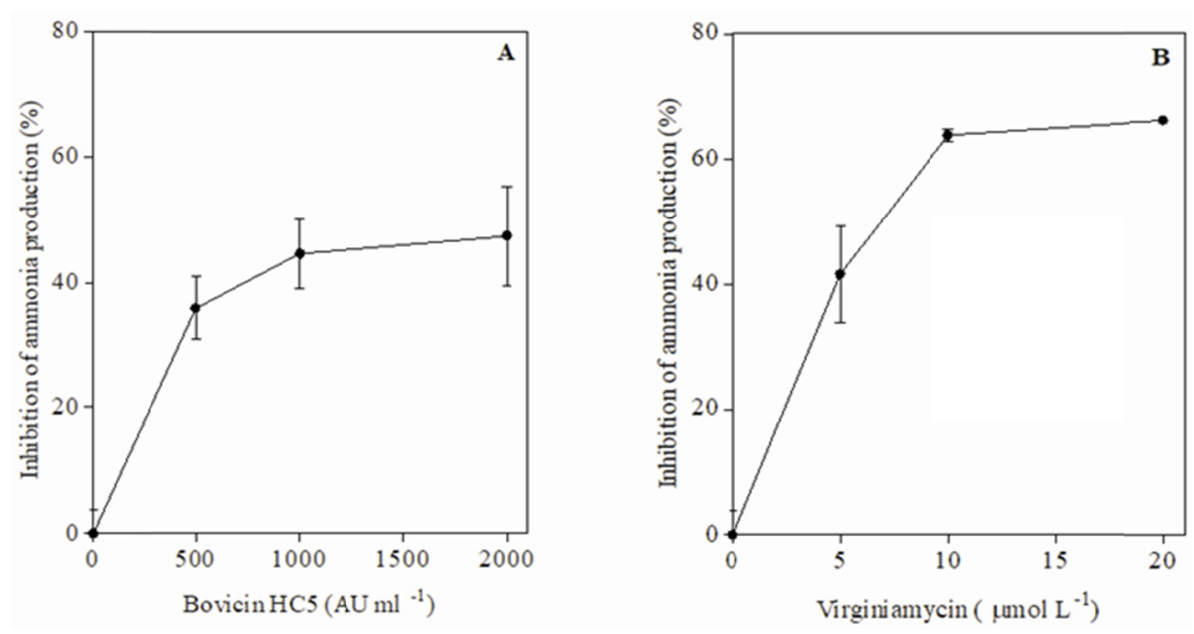

Figure 1. Inhibition of ammonia production by different doses of bovicin HC5 (A) and virginiamycin (B). Ruminal fluid was supplemented with Trypticase $\left(15 \mathrm{~g} \mathrm{~L}^{-1}\right)$ and ammonia concentration was evaluated after 24 hours of incubation $\left(39^{\circ} \mathrm{C}\right)$ under anaerobic conditions

Additives (e.g. antibiotics, bacteriocins, organic acids, enzymes) are often added to the diets of production animals to alter the fermentation products and to increase feed conversion efficiency. Our results indicated that both bovicin HC5 and virginiamycin reduced $(P<0.05)$ the concentration of ammonia and total gas production compared to untreated controls. The inhibition of proteolysis and amino acid deamination can reduce ammonia accumulation in the rumen, potentially increasing the retention of dietary protein by the host (Russell \& Strobel, 1989; Bach et al., 2005). Several species of ruminal proteolytic and amino acid fermenting bacteria appear to be associated with the breakdown of nitrogenous constituents in ruminant diets, and the obligate hyper-ammonia producing bacteria $(\mathrm{HAB})$ seem to play a major role on dietary protein utilization and amino acid deamination in the rumen (Attwood et al., 1998; Bach et al., 2005). Previous studies demonstrated that bacterial species described as HAB (Clostridium sticklandii SR and Peptostreptococcus anaerobius $\mathrm{C}$ ) are sensitive to both antibiotics and bacteriocins (Paster et al., 1993; Callaway et al., 1997). 

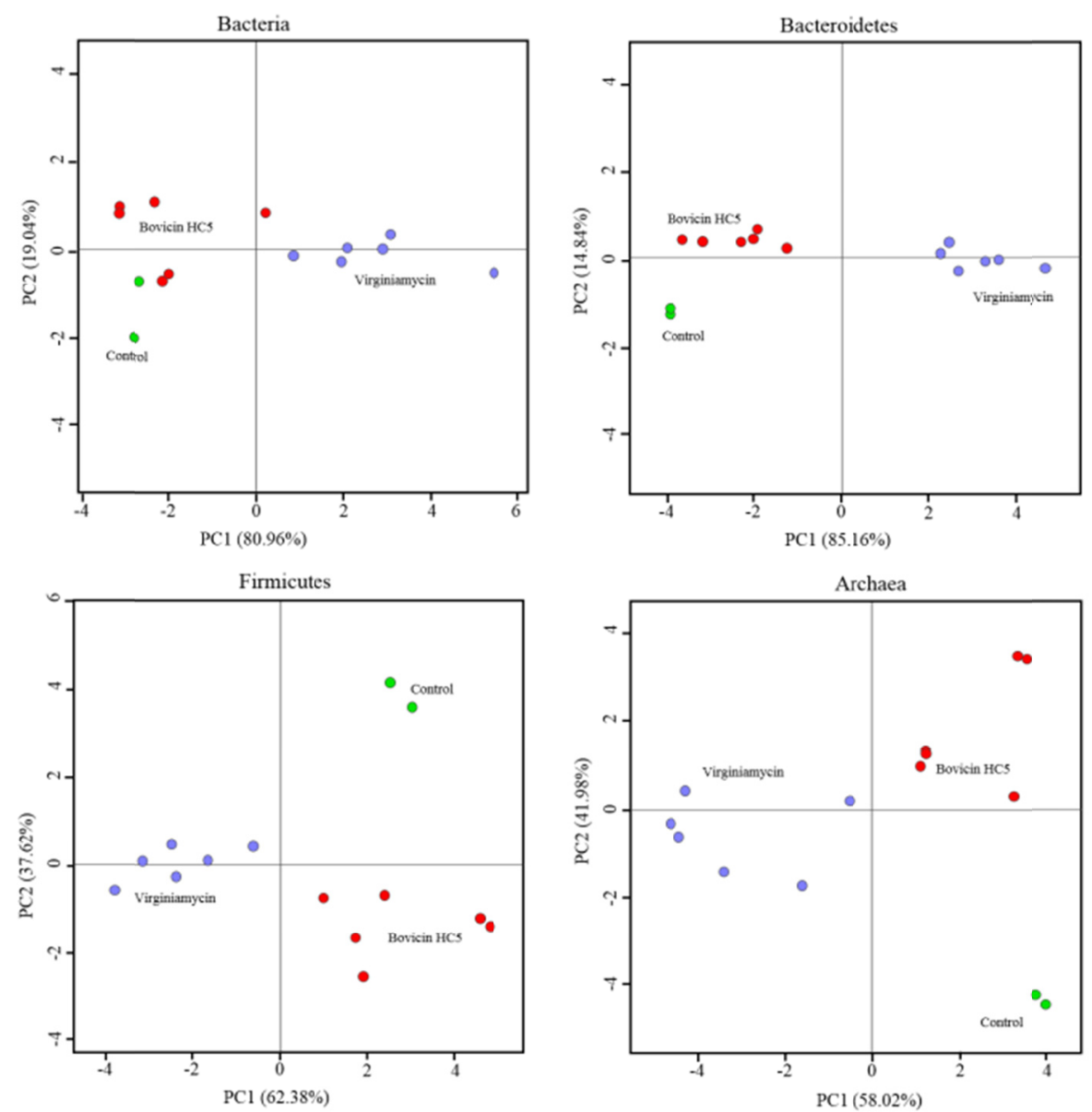

Figure 2. Principal Components Analysis (PCA) showing the effect of bovicin HC5 and virginiamycin on communities of ruminal bacteria and archaea in vitro. The profiles were obtained after nested-PCR amplification of genomic DNA extracted from ruminal fluid containing Trypticase $\left(15 \mathrm{~g} \mathrm{~L}^{-1}\right)$ and added with bovicin HC5 or virginiamycin after 24 hours of incubation $\left(39^{\circ} \mathrm{C}, 200 \mathrm{rpm}\right)$. The PCA was generated using BioNumerics 7.5

Lima et al. (2009) reported that bovicin HC5 was able to inhibit both amino acid deamination and ammonia accumulation in vitro by mixed ruminal bacteria. In vivo studies indicated that monensin reduces the production of ammonia and the specific activity of deamination, being effective against species that ferment amino acids and contribute to the accumulation of ammonia in the rumen (Yang \& Russell, 1993; Ives et al., 2002). Although there is a lack of reports showing the inhibition of HAB by virginiamycin, in vitro and in vivo studies demonstrated that virginiamycin could decrease the concentration of ruminal ammonia (Kook et al., 1999; Ives et al., 2002; Salinas-Chavira et al., 2009).

The addition of virginiamycin and bovicin HC5 reduced both total concentration of volatile fatty acids (VFA) and the proportion of organic acids, which are used as the main energy source by the host. These observations are coherent with previous experiments indicating that nisin, a lantibiotic produced by Lactococcus lactis, also reduced the production of VFA and the acetate/propionate ratio in vitro (Callaway et al., 1997). Additionally, Coe et al. (1999) demonstrated that virginiamycin (up to $250 \mathrm{mg}^{-1 a y}{ }^{-1}$ ) decreased production of VFA and the acetate/propionate ratio during adaptation of Holstein steers to a high concentrate diet. Nonetheless, it should be noted that the effect of bovicin HC5 on VFA concentration could be explained by its ability to inhibit the production of organic acids associated with the use of amino acids as energy sources, such as isobutyric, valeric and isovaleric acids. Bovicin increased the production of the main VFA associated with fiber degradation (acetate, propionate, butyrate) and did not affect the acetate to propionate ratio.

In this study, we investigated changes in microbial community composition caused by bovicin HC5 and virginiamycin using PCR-DGGE and compared differences in richness and diversity of the most predominant bacterial phyla and archaea in in vitro fermentations. Analysis of the composition and abundance of the core 
bacterial community in the rumen of cattle at the genus-level demonstrated that the phyla Bacteroidetes and Firmicutes comprises more than $90 \%$ of the abundance of bacterial taxa in the rumen (Jami \& Mizrahi, 2012). Primers were used to target these abundant groups of rumen bacteria and the band electrophoretic profiles revealed high levels of similarity within treatments and clear differences in microbial community composition among the bovicin HC5 and virginiamycin treatments compared to the untreated controls. It should be noted however, that the community structure of the domain Bacteria and phylum Bacteroidetes in the treatment containing bovicin HC5 was more similar to the controls than the virginiamicin treatment. On the other hand, the community structure of the phylum Firmicutes in the bovicin HC5 treatment was very distinct from the controls, which is coherent with a greater activity of these antimicrobial peptides against the Gram-positive bacteria.

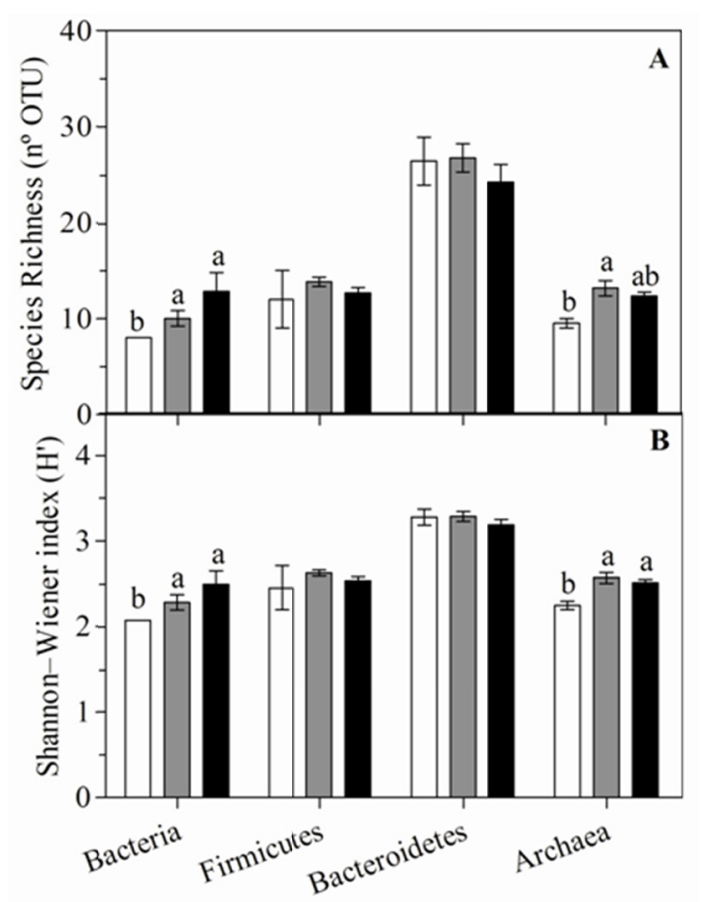

Figure 3. Richness and diversity of rumen Bacteria and Archaea assessed by denaturing gradient gel electrophoresis (DGGE). (A) Species richness and (B) Shannon-Wiener index were calculated from the binary matrix of presence and absence of bands. White bars (Control), grey bars (Bovicin HC5) and black bars (Virginiamycin). Means followed by at least one letter between treatments within the group assessed a 5\% significance level by Tukey test

Virginiamycin and bovicin HC5 have different chemical compositions and show distinct mechanisms of action ( $\mathrm{Ng}$ et al., 2007; Mantovani \& Russell, 2008). Virginiamycin is an antibiotic of the streptogramin family produced by a mutant strain of Streptomyces virginiae (Namwat et al., 2002). This compound consists of two structurally distinct and separately bacteriostatic cyclic peptide antibiotics (factors $\mathrm{M}$ and S). In combination, however, these two components are generally bactericidal, acting synergistically on the bacterial 50S ribosomal subunit to inhibit protein synthesis (Pulsawat et al., 2007). Bovicin HC5 is a class I bacteriocin produced by Streptococcus equinus HC5 isolated from bovine rumen (Mantovani et al., 2002). Bovicin HC5 binds to lipid II to form pores in the cytoplasmatic membrane (Paiva et al., 2011), specially against Gram-positive bacteria (Mantovani et al., 2002; Mantovani \& Russell, 2003). Differences in mechanism of action and spectrum of activity against rumen microbes probably explain the distinct effects observed for bovicin HC5 and virginiamycin on microbial community composition.

PCR-DGGE analysis showed greater diversity and species richness for members in the phylum Bacteroidetes $(P$ $<0.05)$ compared with other taxons. Differences $(P<0.05)$ in Shannon-Wiener index and species richness between treatments were also observed for the domain Bacteria and Archaea. Although methane production has not been determined in this study, the effect of bovicin HC5 and virginiamycin on ruminal archaea communities was also evaluated by PCR-DGGE. Differences $(P<0.05)$ in richness and species diversity were observed only 
for the treatments with the addition of bovicin HC5, and might be related with changes in structure and function of the microbial community.

In conclusion, our results show that both the lantibiotic bovicin HC5 and the non-ionophore antibiotic viriginiamycin had positive effects on ruminal biochemical parameters, but the impacts of these inhibitors on rumen microbial community composition were distinct. Results indicated that bovicin HC5 had more pronounced effects against members of the phylum Firmicutes. Based on the results shown here it appears that both antimicrobials have a protein-sparing effect and it seems plausible that bovicin HC5 could have potential as an additive to manipulate rumen fermentation in cattle production.

\section{Acknowledgements}

This research was supported by the Conselho Nacional de Desenvolvimento Científico e Tecnológico (CNPq; Brasília, Brazil), the Coordenação de Aperfeiçoamento de Pessoal de Nível Superior (CAPES; Brasília, Brazil), the Fundação de Amparo à Pesquisa do Estado de Minas Gerais (FAPEMIG; Belo Horizonte, Brazil) and the INCT Ciência Animal.

\section{References}

Attwood, G. T., Klieve, A. V., Ouwerkerk, D., \& Patel, B. K. C. (1998). Ammonia-hyperproducing bacteria from New Zealand ruminants. Applied and Environmental Microbiology, 64, 1796-1804.

Bach, A., Calsamiglia, S., \& Stern, M. D. (2005). Nitrogen metabolism in the rumen. Journal of Dairy Science, 88, E9-E21. https://doi.org/10.3168/jds.S0022-0302(05)73133-7

Bento, C. B., Azevedo, A. C., Gomes, D. I., Batista, E. D., Rufino, L. M., Detmann, E., \& Mantovani, H. C. (2016). Effect of protein supplementation on ruminal parameters and microbial community fingerprint of Nellore steers fed tropical forages. Animal: An International Journal of Animal Bioscience, 10, 44-54. $10.1017 / \mathrm{S} 1751731115001512$

Bradford, M. M. (1976). A rapid and sensitive method for the quantitation of microgram quantities of protein utilizing the principle of protein-dye binding. Analytical Biochemistry, 72, 248-254. https://doi.org/ 10.1016/0003-2697(76)90527-3

Callaway, T. R., Carneiro De Melo, A. M., \& Russell, J. B. (1997). The effect of nisin and monensin on ruminal fermentations in vitro. Current Microbiology, 35, 90-96. http://doi.org/10.1007/s002849900218

Cameron, A., \& McAllister, T. A. (2016). Antimicrobial usage and resistance in beef production. Journal of Animal Science and Biotechnology, 7, 68. https://doi.org/10.1186/s40104-016-0127-3

Chaney, A. L., \& Marbach, E. P. (1962). Modified reagents for determination of urea and ammonia. Clinical Chemistry, 8, 130-132.

Coe, M. L., Nagaraja, T. G., Sun, Y. D., Wallace, N., Towne, E. G., Kemp, K. E., \& Hutcheson, J. P. (1999). Effect of virginiamycin on ruminal fermentation in cattle during adaptation to a high concentrate diet and during an induced acidosis. Journal of Animal Science, 77, 2259-2268.

Deegan, L. H., Cotter, P. D., Hill, C., \& Ross, P. (2006). Bacteriocins: biological tools for bio-preservation and shelf-life extension. International Dairy Journal, 16, 1058-1071. https://doi.org/10.1016/j.idairyj.2005. 10.026

DeLong, E. F. (1992). Archaea in coastal marine environments. Proceedings of the National Academy of Sciences of the United States of America, 89, 5685-5689.

Ferreira, D. F. (2011). Sisvar: a computer statistical analysis system. Ciência e Agrotecnologia, 35, $1039-1042$.

Hammer, Ø., Harper, D. A. T., \& Ryan, P. D. (2001). Past: Paleontological statistics software package for education and data analysis. Palaeontologia Electronica, 4, 4-9.

Ives, S. E., Titgemeyer, E. C., Nagaraja, T. G., del Barrio, A., Bindel, D. J., \& Hollis, L. C. (2002). Effects of virginiamycin and monensin plus tylosin on ruminal protein metabolism in steers fed corn-based finishing diets with or without wet corn gluten feed. Journal of Animal Science, 80, 3005-3015. https://doi.org/10.2527/2002.80113005x

Jami, E., \& Mizrahi, I. (2012). Composition and similarity of bovine rumen microbiota across individual animals. PLoS One, 7, e33306. https://doi.org/10.1371/journal.pone.0033306 
Kook, K., Sun, S. S., Yang, C. J., \& Myung, K. H. (1999). Influence of monensin and virginiamycin on in vitro ruminal fermentation of ammoniated rice straw. Asian-Australasian Journal of Animal Sciences, 12, 544-547. https://doi.org/10.5713/ajas.1999.544

Lee, S. S., Hsu, J.-T., Mantovani, H. C., \& Russell, J. B. (2002). The effect of bovicin HC5, a bacteriocin from Streptococcus bovis, on ruminal methane production in vitro. FEMS Microbiology Letters, 217, 51-55.

Lewus, C. B., Kaiser, A., \& Montville, T. J. (1991). Inhibition of food-borne bacterial pathogens by bacteriocins from lactic acid bacteria isolated from meat. Applied and Environmental Microbiology, 57, 1683-1688. https://doi.org/0099-2240/91/061683-06\$02.00/0

Lima, J. R., Ribon Ade, O., Russell, J. B., \& Mantovani, H. C. (2009). Bovicin HC5 inhibits wasteful amino acid degradation by mixed ruminal bacteria in vitro. FEMS Microbiology Letters, 292, 78-84. https://doi.org/ 10.1111/j.1574-6968.2008.01474.X

Mantovani, H. C., Hu, H., Worobo, R. W., \& Russell, J. B. (2002). Bovicin HC5, a bacteriocin from Streptococcus bovis HC5. Microbiology, 148, 3347-3352. https://doi.org/10.1099/00221287-148-11-3347

Mantovani, H. C., \& Russell, J. B. (2001). Nisin Resistance of Streptococcus bovis. Applied and Environmental Microbiology, 67, 808-813.

Mantovani, H. C., \& Russell, J. B. (2003). Inhibition of Listeria monocytogenes by bovicin HC5, a bacteriocin produced by Streptococcus bovis HC5. Int J Food Microbiol, 89, 77-83.

Mantovani, H. C., \& Russell, J. B. (2008). Bovicin HC5, a lantibiotic produced by Streptococcus bovis HC5, catalyzes the efflux of intracellular potassium but not ATP. Antimicrobial Agents and Chemotherapy, 52, 2247-2249. https://doi.org/10.1128/AAC.00109-08

Maron, D. F., Smith, T. J. S., \& Nachman, K. E. (2013). Restrictions on antimicrobial use in food animal production: An international regulatory and economic survey. Globalization and Health, 9, 1-11. https://doi.org/10.1186/1744-8603-9-48

Muhling, M., Woolven-Allen, J., Murrell, J. C., \& Joint, I. (2008). Improved group-specific PCR primers for denaturing gradient gel electrophoresis analysis of the genetic diversity of complex microbial communities. The ISME Journal, 2, 379-392. https://doi.org/10.1038/ismej.2007.97

Namwat, W., Kamioka, Y., Kinoshita, H., Yamada, Y., \& Nihira, T. (2002). Characterization of virginiamycin S biosynthetic genes from Streptomyces virginiae. Gene, 286, 283-290.

Ng, C. A., Zhao, W., Dang, J., Bergdahl, M., Separovic, F., Brownlee, R. T., \& Metzger, R. P. (2007). The conformation of acetylated virginiamycin M1 and virginiamycin M1 in explicit solvents. Biochim Biophys Acta, 1774, 610-618. https://doi.org/10.1016/j.bbapap.2007.03.002

Paiva, A. D., Breukink, E., \& Mantovani, H. C. (2011). Role of lipid II and membrane thickness in the mechanism of action of the lantibiotic bovicin HC5. Antimicrob Agents Chemother, 55, 5284-5293. https://doi.org/10.1128/AAC.00638-11

Paster, B. J., Russell, J. B., Yang, C. M., Chow, J. M., Woese, C. R., \& Tanner, R. (1993). Phylogeny of the ammonia-producing ruminal bacteria Peptostreptococcus anaerobius, Clostridium sticklandii, and Clostridium aminophilum sp. nov. International Journal of Systematic Bacteriology, 43, 107-110. 10.1099/00207713-43-1-107

Patra, A. K. (2012). Enteric methane mitigation technologies for ruminant livestock: A synthesis of current research and future directions. Environmental Monitoring and Assessment, 184, 1929-1952. https://doi.org/ 10.1007/s10661-011-2090-y

Pulsawat, N., Kitani, S., \& Nihira, T. (2007). Characterization of biosynthetic gene cluster for the production of virginiamycin M, a streptogramin type A antibiotic, in Streptomyces virginiae. Gene, 393, 31-42. https://doi.org/10.1016/j.gene.2006.12.035

Russell, J. B., \& Strobel, H. J. (1989). Effect of ionophores on ruminal fermentation. Applied and Environmental Microbiology, 55, 1-6.

Rychlik, J. L., \& Russell, J. B. (2000). Mathematical estimations of hyper-ammonia producing ruminal bacteria and evidence for bacterial antagonism that decreases ruminal ammonia production. FEMS Microbiology Ecology, 32, 121-128. https://doi.org/10.1016/S0168-6496(00)00021-0 
Salinas-Chavira, J., Lenin, J., Ponce, E., Sanchez, U., Torrentera, N., \& Zinn, R. A. (2009). Comparative effects of virginiamycin supplementation on characteristics of growth-performance, dietary energetics, and digestion of calf-fed Holstein steers. Journal of Animal Science, 87, 4101-4108. https://doi.org/10.2527/ jas.2009-1959

Shen, J., Liu, Z., Yu, Z., \& Zhu, W. (2017). Monensin and nisin affect rumen fermentation and microbiota differently in vitro. Frontiers in Microbiology, 8. https://doi.org/10.3389/fmicb.2017.01111

Siegfried, B. R., Rückemann, H., \& Stumpf, G. (1984). Method for the determination of organic acids in silage by high performance liquid chromatography. Landwirtsch Forsch, 37, 298-304.

Stevenson, D. M., \& Weimer, P. J. (2007). Dominance of Prevotella and low abundance of classical ruminal bacterial species in the bovine rumen revealed by relative quantification real-time PCR. Applied Microbiology and Biotechnology, 75, 165-174. https://doi.org/10.1007/s00253-006-0802-y

Tagg, J. R., Dajani, A. S., \& Wannamaker, L. W. (1976). Bacteriocins of gram-positive bacteria. Bacteriological Reviews, 40, 722-756.

Theodorou, M. K., Williams, B. A., Dhanoa, M. S., McAllan, A. B., \& France, J. (1994). A simple gas production method using a pressure transducer to determine the fermentation kinetics of ruminant feeds. Animal Feed Science and Technology, 48, 185-197. https://doi.org/10.1016/0377-8401(94)90171-6

Todorov, S. D. (2010). Diversity of bacteriocinogenic lactic acid bacteria isolated from boza, a cereal-based fermented beverage from Bulgaria. Food Control, 21, 1011-1021. https://doi.org/10.1016/j.foodcont.2009. 12.020

Twomey, D. P., Wheelock, A. I., Flynn, J., Meaney, W. J., Hill, C., \& Ross, R. P. (2000). Protection against Staphylococcus aureus mastitis in dairy cows using a bismuth-based teat seal containing the bacteriocin, Lacticin 3147. Journal of Dairy Science, 83, 1981-1988. https://doi.org/10.3168/jds.S0022-0302(00) $75075-2$

Valadares Filho, S. D. C., Costa Silva, L. F., Lopes, S. A., Prados, L. F., Chizzotti, M. L., Machado, P. A. S., ... Furtado, T., (2016). Cálculo de exigências nutricionais, formulação de dietas e predição de desempenho de zebuinos puros e cruzados. Retrieved April 24, 2017, from http://www.brcorte.com.br

$\mathrm{Wu}$, J., Hu, S., \& Cao, L. (2007). Therapeutic effect of nisin $\mathrm{Z}$ on subclinical mastitis in lactating cows. Antimicrobial Agents and Chemotherapy, 51,3131-3135.

Yang, C. M., \& Russell, J. B. (1993). Effect of monensin on the specific activity of ammonia production by ruminal bacteria and disappearance of amino nitrogen from the rumen. Applied and Environmental Microbiology, 59, 3250-3254.

\section{Copyrights}

Copyright for this article is retained by the author (s), with first publication rights granted to the journal.

This is an open-access article distributed under the terms and conditions of the Creative Commons Attribution license (http://creativecommons.org/licenses/by/4.0/). 